\title{
STRENGTHENING COMMUNITY PARTICIPATION IN PREVENTION OF CORRUPTION THROUGH THE REGULATION INTEGRATED PARTICIPATIVE CORRECTIONAL INSTITUTIONS
}

\author{
Wencislaus Sirjon Nansi \\ Fakultas Hukum Universitas Atma Jaya Makassar \\ Jl. Tanjung Alang No.23, Maccini Sombala, Makassar, Indonesia 90224 \\ Email:wencislaus82@gmail.com
}

Submitted : 18/02/2021 Reviewed:26/03/2021 Accepted:31/03/2021

\begin{abstract}
The Article Entitled "Strengthening Public Participation in the Prevention of Corruption through the Regulation of Integrative Participative Institutions" is a normative study that wants to analyze the importance of the role of public participation in controlling the policies of prisons in Indonesia in order to minimize corrupt practices in prisons. The results of the authors'study found that there are obstacles in optimizing the role of public participation in efforts to prevent corruption in prisons, that correctional regulations do not strictly and in detail about community participation. Therefore, the solution offered in this paper is that the government or legislators immediately create regulations that accommodate public participation in controlling correctional policies in Indonesia through participatory correctional regulations. So that this can become a legal basis that provides legal certainty for the public to participate in preventing corruption in prisons.
\end{abstract}

Keywords: Community; Corruption; Integrated; Participator; Regulation

DOI : 10.32801/lamlaj.v6i1.245

\section{INTRODUCTION}

crime of corruption that has occurred in Indonesia is very serious and has had a devastating impact on almost all aspects of life. Corruption not only destroys the economic system but also destroys the democratic order, the political system, the legal system, the government system, and the social order of society in this country ${ }^{1}$. Satjipto Rahardjo, views that the criminal act of corruption that occurs

\footnotetext{
${ }^{1}$ Hartanti Evi,Tindak Pidana Korupsi (Jakarta:Sinar Grafika, 2008), 1
}

in Indonesia is not only entrenched, but has become an organized crime ${ }^{2}$ because the facts show that corruption has systematically and massively infected state institutions, both the Executive and the Legislative, as well as plaguing the judiciary as the last bastion. law enforcement. This corruption crime from year to year does not show good changes or even worse, this is reaffirmed based on the results

\footnotetext{
${ }^{2}$ RE.Baringbing,Catur Wangsa Yang bebas Kolusi Simpul mewujudkan supremasi Hukum (Jakarta:Pusat Kajian Reformasi,2001), 6
} 
of a survey from Transparency International Indonesia that the Corruption Perception Index in 2020 dropped three points to 37 from 40 in the previous year 2019 and Indonesia is in the $102 \mathrm{nd}$ position out of the 180 most corrupt countries surveyed. One aspect that contributes to the high value of corruption in Indonesia is political corruption, corruption in the executive, bodies legislative and judiciary. $^{3}$

data KPKconfirms this, where corruption is spread across almost all state institutions. From the data it is revealed that in 2018-2020 corruption is spread in all institutions such as DPR / DPRD: 130 cases, Heads of Institutions / Ministries: 3 cases, Governors: 3 cases, mayors / regents: 52 cases, judges: 5 cases, prosecutors: 3 cases, lawyer: Case $5^{4}$

The cause of the rampant corruption in Indonesia revealed by several researchers, including: Arifin ${ }^{5}$ identified the factors that cause corruption, including: (1) aspects of individual behavior (2) organizational aspects, and (3) aspects of society where individuals and organizations are located. Furthermore, Bibit Samad Riyanto ${ }^{6}$ said five things that were considered to be potential causes of cor-

\footnotetext{
3 "Indeks Persepsi Korupsi Indonesia Pada 2020 Melorot 3 Poin," Antaranews. Com, last modified 2021, accessed February 9, 2021, https:/www.antaranews. com/berita/1972407/indeks-persepsi-korupsiindonesia-pada-2020-melorot-3-poin\#: :text=Jakarta (ANTARA) - Indeks Persepsi,dari 180 negara yang disurvei.

4 "TPK Berdasarkan Profesi/Jabatan," KPK Komisi Pemberantasan Korupsi, last modified 2021, accessed February 2, 2021, https://www.kpk.go.id/id/statistik/ penindakan/tpk-berdasarkan-profesi-jabatan.

${ }^{5}$ Arifin, Buku Pendidikan Anti Korupsi Untuk Perguruan Tinggi (Jakarta: Kementerian Pendidikan dan Kebudayaan RI, 2011),53

6 Bibit Samad Rianto, Bunga Rampai Potret Penegakan Hukum di Indonesia (Jakarta: Komisi Yudisial Republik Indonesia,2009)
}

ruption. The first is the political system, which is marked by the emergence of statutory regulations, such as regional regulations and other regulations; second, is the moral intensity of a person or group; third is minimal remuneration or income (income); fourth is supervision both internal and external; and fifth is a ruleabiding culture.

Based on this, various efforts have been made, both through prevention and repressive measures. Various efforts have been made but corrupt practices continue to occur. According Indriyanto Seno Adji that in order to minimize the corruption that has become a problem of systematic and structured very powerful intact rooted and permanent nature, required a maximum effort for law enforcement, namely through the approach of the system itself (systematic ${ }^{7}$ approach). The systematic approach offered by Indriyanto Seno Adji has three layers of meaning, as follows: ${ }^{8}$ 1) Maximizing the role of the Criminal justice system in a broad manner; 2) Coordination and coherence between law enforcement officials (police, prosecutors and courts, including even lawyers); and 3) Legal reforms covering the legal structure, legal substance and legal culture.

One of the important parts in law enforcement efforts in Indonesia, including the eradication of corruption, is reforming correctional institutions. Based on the Act. No. 12 of 1992 concerning Correctional Institutions in Article 1 point 3, Correctional Institutions are places to carry out the development of Pris-

\footnotetext{
${ }^{7}$ Indriyanto Seno Adji, Korupsi Kebijakan Aparatur Negara dan Hukum Pidana (Jakarta:Diadit Media,2006), 374

8 Ibid
} 
oners and Correctional Students ${ }^{9}$, who carried out in an integrated manner between the supervisor, the fostered, and the community to improve the quality of the Correctional Assistance Citizens in order to realize mistakes, improve themselves, and not repeat criminal acts. ${ }^{10}$

Ideally, the prison institution (Penitentiary) is a place to foster criminals so that they are deterred from committing crimes again. However, based on the results of the previous author's research, the purpose of the punishment failed (not achieved) because it was caused by many practices irregularities that occur in prisons such as buying and selling offacilities and infrastructure prison, being free to enter and exit the prison, ${ }^{11}$ even free to control crime from inside the prison. One of the crimes that are controlled from within prisons is narcotics crime. Convicted in the Correctional Institution (Prison) controlling drug trafficking is enough with the cell phones smuggled into prisons. ${ }^{12}$.

All these things happened not solely because of the courage of the prisoners them-

\footnotetext{
${ }^{9}$ Article 1 No.3 Law of the Republic of Indonesia on Number 12 of 1995 Concerning Correctional Institution

${ }^{10}$ Article 1 No.2 Law of the Republic of Indonesia on Number 12 of 1995 Concerning Correctional Institution

${ }^{11}$ Rakhmat Nur Hakim, "Pimpinan DPR Minta Napi Koruptor Tak Diistimewakan Di Lapas," Kompas.Com, last modified 2018, accessed December 5, 2020, https://nasional.kompas.com/ $\mathrm{read} / 2018 / 07 / 24 / 14081701 /$ pimpinan-dpr-mintanapi-koruptor-tak-diistimewakan-di-lapas.

${ }^{12}$ Rangga Baskoro, "90 Persen Peredaran Narkoba Berasal Dari Dalam Lapas, Pengendalian Cukup Dengan Ponsel," Wartakotalive.Com, last modified 2019, accessed February 8, 2020, https://wartakota. tribunnews.com/2019/12/02/90-persen-peredarannarkoba-berasal-dari-dalam-lapas-pengendaliancukup-dengan-ponsel.
}

selves, but there were corrupt practices carried out by unscrupulous prison officials. In addition, there is no external control mechanism that is carried out on all correctional activities, so that the correctional institution becomes a closed place or is isolated from control the community.

The government, as the holder of the highest authority in the State of Indonesia, must have a set of regulatory policies in order to open the widest possible space for all elements of the nation, especially society, to participate in providing oversight of various social policies as well as all forms of legal protection as the implications of participating in various irregularities in institutions. community from the threat of the parties who feel aggrieved. This is in line with the opinion of Michael Johnston and Sahre J.Kpudehcarry ${ }^{13}$ who said that in order to fight corruption it is important toout anmovement social integrativeinvolving government and private figures in order to mobilizeparticipation and advocacy social community.

The role of the public in preventing corrupt practices in Indonesia has actually been regulated in various laws and regulations, however this is generally regulated across sectors and institutions. In connection with community participation in prevention of corruption ininstitutions correctional has not been set explicitly. Therefore, this paper wants to describe two problems, namely: 1) To what extent is the urgency of the community's participatory role in efforts to eradicate corruption in Indonesia, especially what occurs

\footnotetext{
${ }^{13}$ Vishnu Juwono, Melawan Korupsi: Sejarah Pemberantasan Korupsi Di Indonesia 1945-2014, ed. Candra Gautama and Ining Isaiyas (Jakarta: Kepustakaan Populer Gramedia, 2018).
} 
inInstitutions Correctionaland 2) How an effective regulatory model in optimizing public participation in preventing and overseeing corruption crimes that occur in prisons. So that from the issues raised, the author can provide alternative ideas forpolicy makers in regulative order to produce effective regulations in encouraging the optimization of the role of public participation in preventing corrupt practices in Indonesia, especially those that occur in prisons.

\section{METHOD}

In answering the two problems raised in this paper as previously described, the authors useresearch methods normative with a juridical and conceptual approach. The juridical approach is to examine and study various laws and regulations governing public participation in efforts to prevent corruption in Indonesia, especially in prisons. Meanwhile, the conceptual approach is to dissect and elaborate various concepts and theories related to community participation in corruption prevention. Sources of legal materials used are primary legal materials obtained from laws and regulations on corruption and prisons, while secondary legal materials are obtained from various books and journals related to public participation in efforts to prevent corruption in Indonesia. Furthermore, the data is processed and analyzed using prescriptive analysis techniques.

\section{ANALYSIS AND DISCUSSION Urgensitas Community Participatory Role Against Corruption Prevention Efforts In Prison In Indonesia}

Corruption as an extraordinary crime is a crime that is universal, and threatened the welfare of the whole community in the world, including in Indonesia. Corruption crimes occur not only in Indonesia, but also throughout the world. This is as stated in the preambule 4thof the United Nations Convention Against Corruption, 2003 which states: "Believing that corruption is no longer a local problem, but a transnational phenomenon that affects the entire society and economy which encourages international cooperation to prevent and control it essential ${ }^{14}$

Based on this, all countries in the world agree that the crime of corruption is a form of crime that can be categorized as an "extraordinary" crime. It is called extraordinary because it is generally carried out systematically, has actors intellectual, involves stakeholders in an area, including involving law enforcement officials, and has a "destructive" impact on a broad spectrum ${ }^{15}$. These characteristics make eradicating corruption even more difficult if you only rely on ordinary law enforcement officers, especially if corruption has become a culture and has infected all aspects and levels of society.Therefore ${ }^{16}$, the operationalization of corruption eradication must be carried out comprehensively, integrally, and holistical$1 \mathrm{ly}{ }^{17}$

\footnotetext{
${ }^{14}$ Anastasia Reni Widyastuti, "Disfungsionalisasi Birokrasi Sebagai Kendala Dalam Pemberantasan Korupsi," Yustisia Jurnal Hukum 4, no. 3 (2015): 684, https:/jurnal.uns.ac.id/yustisia/article/view/8700.

${ }^{15}$ Hambali Thalib, Ahmad Ramadhan, and Hardianto Djanggih, "The Corruption Investigation In The Regional Police of Riau Islands, Indonesia," Rechtsidee Universitas Muhammadiyah Sidoarjo 4, no. 1 (2017): 71-86, http://ojs.umsida.ac.id/index. $\mathrm{php} /$ rechtsidee/article/view/988.

${ }^{16}$ Sarmadan Pohan, "Perbandingan Lembaga Anti Korupsi Di Indonesia Dan Beberapa Negara Dunia," JUSTITIA : Jurnal Ilmu Hukum dan Humaniora 1, no. 1 (2018): 271-303, http://jurnal.um-tapsel.ac.id/ index.php/Justitia/article/view/44.

${ }^{17}$ Bambang Waluyo, "Optimalisasi Pemberantasan Korupsi Di Indonesia,” Jurnal Yuridis 1, no. 2 (2014):
} 
The corruption epidemic is currently the enemy. great nation, because currently corruption is not only carried out by individuals but is also carried out systematically by institutions, be it the executive branch, the legislature has also infected the law enforcement agencies themselves.

From the data released by the KPK in the last three years 2018-2020, Corruption crimes have penetrated all State institutions as in the following table: ${ }^{18}$

\begin{tabular}{|l|l|l|l}
\hline Agencies & $\mathbf{2 0 1 8}$ & $\mathbf{2 0 1 9}$ & $\mathbf{2 0 2 0}$ \\
\hline DPR / DPRD & 4 & 7 & 0 \\
\hline $\begin{array}{l}\text { Ministries } \\
\text { Institutions }\end{array}$ & 47 & 44 & 2 \\
\hline / Bumnbumd & 5 & 17 & 5 \\
\hline COMMISSION & 0 & 0 & 0 \\
\hline $\begin{array}{l}\text { Government } \\
\text { Provincial }\end{array}$ & 29 & 11 & 6 \\
\hline $\begin{array}{l}\text { Pemkab / Pemkot } \\
\text { Total }\end{array}$ & 114 & 66 & 30 \\
\hline
\end{tabular}

problem of the involvement of all elements in almost all state institutions and law enforcement in corruption crimes signals that corruption is a very serious and extraordinary problem that requires the involvement of all parties. One of the most important elements is active community participation.

Of the many practices corrupt that occur in institutions law enforcement, one of which is affected by the corruption epidemic is the Penitentiary.institutions Correctional based on the Law of the Republic of Indonesia Number 12 of 1995 Concerning Corrections were born on the basis of consideration as a series of law enforcement aimed at making prisoners aware of their mistakes, improving

169-182, https://ejournal.upnvj.ac.id/index.php/ Yuridis/article/view/149.

18“TPK Berdasarkan Instansi," KPK Komisi Pemberantasan Korupsi, last modified 2021, accessed February 2, 2021, https://www.kpk.go.id/id/statistik/ penindakan/tpk-berdasarkan-instansi. themselves, and not repeating criminal acts so that they can be accepted back by the community, can play an active role in development, and can live naturally as good and responsible citizens. ${ }^{19}$

However, the idealism of the Correctional Law in many practices is far from burning. Prison in Indonesia has many problems. Iqrak Sulhin ${ }^{20}$ in his book Discontinuity $\mathrm{Pu}-$ nitive Penological(A Genealogical Analysis of Imprisonment) raises several problems in correctional institutions in Indonesia, which are : a) the problem of autonomy, which is a problem that arises because of the absence of autonomy from prison as an organization. As part of the state bureaucracy, structural conditions cause planning and budgeting to be highly dependent on state policies, especially with regard to budgeting to meet the minimum needs (basic rights) of prisoners and carrying out development programs; b) technologicalproblems (problems of technology), technology that is What is meant here is the management in the implementation of coaching as well as the strategy and instrumentation of the guidance itself. Supporting facilities that are not proportional, will have an impact on the lack of the prison's ability to carry out the guidance process, such as the lack of variety in methods of guidance which must be adjusted to the classification of prisoners or prisoners, lack of infrastructure and also the lack of capacity of officers in providing guidance; c) the problem of control (problem of control) is related to the problem of prisons in maintaining the level of compliance of their

\footnotetext{
${ }^{19}$ Considering Section C Law of the Republic of Indonesia on Number 12 of 1995 Concerning Correctional Institution

${ }^{20}$ Iqrak Sulhin, Diskontinuitas Penologi Punitif,Sebuah Analisis Genealogis Terhadap Pemenjaraan (Jakarta:Prenada Media Group, 2016), 131-132.
} 
inmates. Prison is considered a closed institution. Therefore, external supervision, whether carried out by other authorized government agencies or by the community, tends to be difficult. This resulted in the occurrence of many irregularities carried out in prison by prison officials or authorities; d) the problem of prison overcrowd, in which the number of residents exceeds the maximum capacity. This has led to problems of poor prison conditions, lack of quantity and quality of staff, inconvenience of staff and the mixing of prisoners.

Iqrak Sulhin's notes were later affirmed with many examples of cases which showed that the correctional institutions still had many problems that had to be resolved immediately. In a research conducted by ICW in 6 (six) major cities in Indonesia regarding patterns of corruption in the judiciary in 2001, it was found that there were at least 5 (five) patterns of corruption that occurred in correctional institutions or detention centers, which are $:^{21}$

1. Provision and treatment of facilities. specifically while in custody. By paying a certain amount of money to the officers, inmates will get different treatment from other inmates. Special facilities can also be provided, for example a separate cell separate from other prisoners, nutritious meals and drinks, television furniture, refrigerators, air conditioners, cellphones, and so on. If agreed, even the cell room can be transformed into a temporary office for a prisoner who is actually a businessman.

2. Providing security services. In general,

\footnotetext{
${ }^{21}$ Agus Hariadi, "Suatu Dilema Dalam Pembinaan Narapidana Koruptor Di Lembaga Pemasyarakatan," Jurnal Legislasi Indonesia 13, no. 3 (2016): 303, https://e-jurnal.peraturan.go.id/index.php/jli/article/ view/157.
}

conditions for detention centers or prisons in Indonesia are not as safe as imagined. The disproportionate number of prison guards has made violence rampant in prisons. This condition is exploited by a number of individuals in the prison environment and prisoners who are kept by officers to ask for security services. If security money is not given, it is certain that the threat of violence will be experienced by the prisoners.

3. Granting permission to leave prison. Actually there is nothing wrong with the prisoner leaving the prison. For example, for medical treatment or on leave to visit family. However, the procedure that must be fulfilled is that there is a permit issued by the head of the Lapas and Kakanwil of the Ministry of Law and Human Rights. The right to leave the prisoner is clearly regulated in Law Number 12 of 1995 concerning Corrections (Law on Corrections). Article 14 letter d regulates the right to get health services and Article 14 letter $\mathrm{j}$ regulates the right to leave to visit family. For example, marrying off children, getting married or visiting close family members..

4. Providing remission. One of the quick ways that prisoners can use to immediately breathe free air is through the provision of remissions (reduced sentences). Remission is one of the rights of prisoners as regulated in the Law on Corrections. If a prisoner has good behavior while in prison, the head of the prison can propose to the Minister of Law and Human Rights to grant remissions to the prisoner concerned.

5. Fees for guests or visitors. It is common knowledge that when a family or guest 
wants to visit a prisoner, it turns out that there are "informal" charges that seem to have been standardized. Not only money, food was often asked for by the guards. By paying a larger number of bribes, guests can even visit prisoners without being tied to visiting hours.

In addition to the data disclosed by ICW, the data collected byresearch teamTirto ${ }^{22}$ on the practice of irregularities in correctional institutions involvingofficials and prisonconvicts corruptioninclude Anggoro Widjojo, convicted in a corruption case in the procurement project of the Integrated Radio Communication System at the Ministry of Forestry 2007. Anggoro was then transferred to $\mathrm{Gu}-$ nung Sindur Prison on February 7, 2017 because while he was in Sukamiskin Prison, he was often caught going out of prison. He even had time to live in an apartment in Bandung, which is located not far from the Sukamiskin Prison. Another case is Romi Herton, who was transferred from the Sukamiskin Prison to the Gunung Sindur Prison on 9 February 2017 because he was proven to have misused his exit permit. Apart from that, Rachmat Yasin was also caught visiting a rented house in the Panorama Alam Parahyangan Complex in December 2016. Far back, to be precise in September 2015, a photo of Gayus Tambunan was circulating eating at a restaurant in Jakarta. Even though he is currently serving a sentence at the Sukamiskin Prison in connection with a tax corruption case. In October 2014, the former Mayor of Bekasi, Mochtar Mohamad, was also caught having dinner at a South

\footnotetext{
${ }^{22}$ Abdul Aziz, "Mengapa Napi Korupsi Terus Ditempatkan Di Lapas Sukamiskin?," Tirto.Id, last modified 2018, accessed February 8, 2020, https:// tirto.id/mengapa-napi-korupsi-terus-ditempatkan-dilapas-sukamiskin-cPEt.
}

Jakarta restaurant, even though at that time he was a convict. The last case is the Corruption Eradication Commission (KPK) securing the head of the Sukamiskin Wahid Husen and his wife Dian Anggraini in a Hand-Catching Operation (OTT) in Bandung, Friday (20/7) night. Wahid was arrested on suspicion of accepting bribes from corruption convict Fahmi Darmawansyah in order to get a luxurious cell and facilities to get in and out of detention freely. ${ }^{23}$

Irregular practices such as corruption and bribery that occur in these correctional institutions certainly need attention serious. Therefore, prevention of corruption is not only charged by agencies, law enforcement but also required theparticipation active of all stakeholders including the public.

Referring to the opinion of Gillespie and Okruhlik, ${ }^{24}$ determining what efforts are most effective in eradicating corruption is also a debate in much of the literature on corruption. In essence, this debate seeks to offer aapproach multi-perspective/ comprehensivethat is considered to provide substantial and sustainable results in overcoming corruption. There are at least 4 (four) strategies to eradicate corruption, namely: (1) strategies related to society; (2) strategies legal; (3) market-related strategies; and (4) strategies related to politics.

\footnotetext{
${ }^{23}$ Ihsanuddin, "Kronologi OTT Kalapas Sukamiskin Dan Terungkapnya Fasilitas 'Wah' Para Napi," Kompas.Com, last modified 2018, accessed January 18, 2021, https://nasional.kompas.com/ $\mathrm{read} / 2018 / 07 / 22 / 05332271 / \mathrm{kronologi-ott-kalapas-}$ sukamiskin-dan-terungkapnya-fasilitas-wah-paranapi?page $=$ all.

${ }^{24}$ Teguh Kurniawan, "Peranan Akuntabilitas Publik Dan Partisipasi Masyarakat Dalam Pemberantasan Korupsi Di Pemerintahan," Bisnis \& Birokrasi, Jurnal Ilmu Administrasi dan Organisasi 16, no. 2 (2009): 119, http://journal.ui.ac.id/index.php/jbb/article/ view/612.
} 
Meanwhile, according to Widjajabrata and Zacchea, ${ }^{25}$ there are 4 (four) strategies that can be carried out in order to provide different results in efforts to eradicate corruption, namely: (1) focusing on law enforcement and punishing perpetrators; (2) involving the public in preventing and detecting corruption; (3) undertaking major public sector reform efforts, which include activities to strengthen accountability, transparency, and supervision; and (4) strengthening the rule of law, improving the quality of anti-corruption laws, handling money laundering, and promoting good governance.

In various corruption cases that can be processed up to the Corruption Crime Court, precisely because of reports from the public. According to Satjipto Rahardjo ${ }^{26}$ Pertama, it was realized that legal capacity was limited. Empowering everything to the law is unrealistic and wrong. We leave fate to institutions that do not have the absolute capacity to accomplish tasks on their own. It is empirically proven that in order to carry out its duties, it always needs help, support, and additional public power. Second, it turns out that people still have autonomous power to protect and organize themselves. That power has temporarily sunk under the conditions oflaw modern, which in fact is the law of the state. Since its emergence 200 years ago, the state has wanted to monopolize power, including making laws, creating structures (bodies and institutions) and regulating the process. No other power and power can rival and all genuine powers must step aside. Even so, he does not die, but still exists and works silently (latent). The

\footnotetext{
${ }^{25}$ Ibid., 120

${ }^{26}$ Satjipto Rahardjo, Membedah Hukum Progresif (Jakarta: Penerbit Kompas , 2006), 80-81.
}

existence of the community in carrying out social interactions and social integration movements to support the eradication of corruption, because it is the citizens who are also affected by the negative implications of the phenomenon of corruption. Society must be considered as a system consisting of interrelated parts and mutually influence each other. Although it is acknowledged that social integration can never be achieved completely, in principle the social system always tends to move towards dynamic continuity.

Irfan Islamy ${ }^{27}$ stated that there are at least 8 (eight) benefits that will be achieved if it involves community participation in the development process, which are : The

1. community will be increasingly ready to accept and implement development ideas;

2. Relations between the community, government and the legislature will improve;

3. The community has a high commitment to the institution;

4. The public will have greater trust in the government and legislature and are willing to work together in handling public duties and affairs;

5. If the community already has trust and accepts development ideas, then they will also feel they have a responsibility.

6. Quality / quality of decisions / policies that will be taken will be better because the community participates in providing input;

7. Will streamline communication from the

\footnotetext{
${ }^{27}$ Mawardi Khairi, "Partisipasi Masyarakat Dalam Upaya Penegakan Hukum Peraturan Daerahpersepektif Teori Negara Hukum," Selisik 3, no. 1 (2017): 94, http:// journal.univpancasila.ac.id/index.php/selisik/article/ view/658.
} 
bottom up and from the top to the bottom;

8. Can facilitate cooperation, especially to solve complex and complex joint problems.

From the various descriptions, for the author in relation to the prevention of corruption in correctional institutions, the participation of the community at least has a positive impact:

1. As a form of direct participation in the framework of a democratic society, where the State and its institutional apparatus and the entire work process must come from the wishes of the people and aims for the interests of the people.

2. As an embodiment of respect for human rights as recognized in the 1945 constitution, namely the right to participate in government.

3. Take part in law enforcement efforts in assisting institutionslaw enforcementin thesystem criminal justice.

4. Creating a professional and transparent prison atmosphere, so as to prevent various deviant practices that occur in the correctional institution.

5. Assisting the State and government to formulate sound and progressive policies in law enforcement efforts, especially the prevention of corruption crimes in correctional institutions.

\section{Effective Regulatory Models in Increasing Communityas Efforts to Prevent Corrup- tion in Prison in Indonesia \\ ParticipationEfforts to regulate community involvement in efforts to prevent and eradi- cate corruption in Indonesia can be found in several regulations that are scattered in sev- eral laws and regulations, namely:}

\section{KUHAP (Book Law Code of Criminal Procedure)}

In article 108, paragraph 1 and paragraph 3 of Law No. 8 of 1981 of About the Book of Law the Criminal Procedure (Penal Code), asserts that: (1) Any person who suffered, saw, witnessed and or being a victim ofincident anwhich constitutes a criminal act has the right to submit a report or complaint to the investigator and / or investigator, either verbally or in writing; (2) Every civil servant in carrying out his / her duties who knows about an incident which constitutes a criminal act is obliged to immediately report it to the investigator or investigator.

2. Law No. 31 of 1999 in conjunction with Law No. 20 of 2001 concerning the Eradication of Corruption Crime

In article 41 paragraph 2 it is stated that the role of the community in eradicating Corruption can be realized in the form of: The

a) right to seek, obtain and provide information on the existence of allegations of Corruption Crime;

b) The right to obtain services in seeking, obtaining and providing information on the suspicion of a Corruption Crime to law enforcers handlingcases Crime Corruption;

c) The right to convey suggestions and opinions responsibly toenforcers lawwho handle Corruption Crime cases;

d) The right to obtain answers to questions about the report given to law enforcers within a maximum period of 30 (thirty) days;

e) The right to obtain legal protection in terms of: Implementing the rights referred to in letters a, b, and c; and requested to be present in the process of investigation, investigation and in 
court hearings as a reporting witness, witness or expert witness, in accordance with the provisions of the prevailing laws and regulations.

3. Law Number 28 of 1999 concerning Clean and Free State Administration from KKN

Article 8 paragraph 1 states that the role of the community in state administration is the right and responsibility of the community to participate in realizing a clean State Administrator. Then in the explanation of article 8 paragraph 1 , it is stated that the public participation as referred to in this paragraph is the active role of the community to participate in realizing State Administrators who are clean and free from corruption, collusion and nepotism, which are carried out in compliance with legal, moral and social norms. prevailing in society Meanwhile, article 9 of Law Number 28 Year 1999 describes the manifestation of community participation, among others;

a) The right to seek to obtain and provide information on the administration of the State

b) Right to obtain equal and fair services from State Administrators

c) Right to convey suggestions and opinions responsibly towards the policies of State Administrators

d) Right to legal protection

4. Law Number 30 of 2002 concerning the Corruption Eradication Commission in Article 1 paragraph 3 The Corruption Eradication Commission Law regulates the issue of community participation, which states that the eradication of corruption is a series of actions to prevent and eradicate criminal acts of corruption through coordination, supervision, monitoring, investigation, investigation, prosecution and examination in court sessions with community participation based on applicable statutory regulations.

5. Government Regulation of the Republic of Indonesia Number 43 of 2018 concerning Procedures for Implementing Community Participation and Giving Awards in the Prevention and Eradication of Corruption Crimes

In order to provide high motivation to the community, towards efforts to prevent and eradicate Corruption, the government issued a regulation, namely the Government Regulation of the Republic of Indonesia Number 43 of 2018 concerning Procedures for Implementing Community Participation and Giving Awards in the Prevention and Eradication of Corruption Crimes.

In this government regulation, several things are regulated:

- Article 5 "The public can provide information about the alleged corruption crime to:

a) authorized officials in public bodies; and / or

b) Law Enforcers".

- Article 7(1). "The provision of information to law enforcers as meant in Article 5 letter $\mathrm{b}$ is done by making a report". (2) "The report as referred to in paragraph (1) can be submitted orally or in writing, either through electronic or non-electronic media. (3) "In the event that the report as referred to in paragraph (2) is submitted orally, the Law Enforcer or authorized officer is obliged to record the report in writing". (4) "The report as referred to in 
paragraph (3) must be signed by Reporting Parties and Law Enforcement Officials or authorized officers".

- Article 8(1) "Reports regarding the allegation of criminal acts of corruption as referred to in Article 7 contain at least: a. Reporting identity; and b. a description of the facts of allegedhave taken place corruption"(2)" In presenting the report referred to in paragraph (1) must be accompanied by supporting documents at least: a. photocopy of identity card or other personal identity; and b. documents or information related to the reported alleged corruption crime".

- Article 9 (1) "Law Enforcement is obliged to carry out an examination of the report as referred to in Article 8 administratively and substantively". (2) "The examination as referred to in paragraph (1) shall be carried out within 30 (thirty) working days from the date of the report. be accepted". (3) "In the substantive examination process as referred to in paragraph (1), Law Enforcers may request information from the Reporting Party". (4) "The reporting by the Reporting Party as referred to in paragraph (3) can be delivered orally and / or in writing. (5) In the event that the Reporting Party does not provide the information as referred to in paragraph (3), the followup to the report shall be determined by theEnforcer Law.

- Article 10 (I) "Reporting parties have the right to raise questions regarding their reports provided to law enforcers as referred to in Article 7 paragraph (1)". (2) "Law enforcers are obliged to provide answers to questions regarding the report as referred to in paragraph (1) within a period of no later than 30 (thirty) days from the date the questions are asked".

- Article 12: With regard to protection legal

regulated in article Article 12 (1) The right to obtain legal protection as referred to in Article 2 paragraph (2) letter e is given by Law Enforcement to the Community in terms of:

a) exercising their rights as referred to in Article 2 paragraph ( 2) letter a, letter $\mathrm{b}$, and letter $\mathrm{c}$; and

b) requested to be present in the process of investigation, investigation and examination at court proceedings as Reporters, witnesses, or experts. (2) protection Legalis given to Reporters whose reports contain the truth. (3) protection Legalas referred to in paragraph (1) shall be implemented in accordance withprovisionsthe oflaw.-undangan (4) in providing legal protection as described in paragraph (1), law Enforcement can work with the Witness and Victim Protection Agency

\section{- Article 13-23: Set on Form Award} Article 13

(1)People who contributed to help efforts the prevention, eradication, or disclosure of criminal acts of corruption is rewarded.

(2) The award as intended in paragraph (1) is given to:

a.People who are actively, consistently and sustainably engaged in the prevention of corruption; 


\author{
or \\ b. Reporters.
}

(3)The award as referred to in paragraph (2) shall be given in the form of: a) a certificate; and / or b). premium.

Referring to some of these laws and regulations, actually the regulations regarding the role of public participation in the prevention and eradication of corruption have been accommodated in theseregulations laws and. However, it is only related to the prevention of corruption in various sectors and across institutions in general. Meanwhile, in relation to the specifications for the prevention of corruption in correctional institutions, it has not been specifically regulated. For the author, it is important to think ahead, because based on the data described earlier, corruption, such as bribery, is so prevalent in correctional institutions. This is supported by the condition of the correctional institutions which are closed away from the public's observation in general.

If you look closely at UU.No. 12 of 1995 concerning Corrections, is not regulated specifically and in detail about the extent to which space is provided for public participation in the supervision of correctional institutions in efforts to prevent corruption in correctional institutions. In the correctional law, it only regulates the Correctional Advisory Center and the Correctional Observer Team as regulated in Chapter IV with its description in Article 45, namely: The

(1) Minister establishes a Correctional Advisory Center and Team Correctional Observer.

(2) The Correctional Advisory Center has the duty to provide advice and or considerations to the Minister.

(3) Correctional Advisory Center as intended in paragraph (2) consists of experts in the field of correctional who are representatives of related government agencies, non-government agencies and other individuals.

i. Correctional Observers Team consisting of officials of LAPAS, BAPAS or other relevant officials in charge of:

a. give advice regarding the form and program of guidance and guidance in implementing the correctional system;

b. make an assessment of the implementation of the guidance an guidance program; or

c. receive complaints and complaints from the Correctional Assistance Citizens.

For the author, the Correctional Law only regulates the internal supervision of prisons established by the government itself. It does not open up space for external supervision carried out or initiated by the wider community. According to the author, this is aproblem normative in the correctional law that has not seriously managed and handled correctional institutions that are professional and transparent. Penitentiaries eventually become closed spaces away from the public's scrutiny, so that in the end the prison is no longer an effective part of the criminal justice system to deter perpetrators, but becomes a new habitat for many irregularities, including corruption and bribery.

Therefore it is important to regulate normatively the role of public participa- 
tion in supervising correctional institutions in order to prevent and overcome corrupt practices in correctional institutions. At least there are a few important things set:

1. Restrictions or definition of the responsibilities and obligations of the role of community participation in the prevention and control of corruption in institutions of Corrections

2. Forms role of the community towards the prevention and control of corruption in institutions of Corrections

3. Mechanism delivery of public participation

4. Legal Protection against participation community

5. Respect for public participation

If the things described are carried out and it is also followed by harmonization and synchronization of various existing laws and regulations governing public participation in preventing and overcoming corruption crimes. It is believed by the author that it will create legal certainty for the community in guarding correctional institutions in Indonesia to be free from corrupt practices. For this reason, it is important that participatory correctional regulations are initiated by legislators. There are at least two alternatives that can be done:

1. The first alternative, Revision of Law no. UU no. 12 of 1995 concerning Corrections, by including a Special Chapter on the Role of Community Participation in Supervision of Correctional Institutions in Corruption Prevention Efforts in Correctional Institutions.

2. The second alternative, creating a special regulation in the form of a law that specifically regulates the Role of Community Participation in Supervision of
Correctional Institutions in efforts to prevent corruption.

\section{CONCLUSION}

Correctional facilities are one of the important nodes of the entire flow of the law enforcement process, especially the prevention of corruption in Indonesia. The performance of correctional institutions and all their apparatuses is one of the important variables whether law enforcement in Indonesia is effective or not. In supporting the performance of law enforcement officials, synergy and the role of community participation are needed in controlling and overseeing the development process of prisoners in prisons. The role of the community is very important given the many irregular practices that have led to bribery and corruption in prisons.

This increase in community participation, of course, must be supported by various government regulations and policies. In Indonesia, there are several policies and laws and regulations that regulate community participation. However, the various policies seem to overlap one another. Even the main regulation regarding correctional facilities is the Law. No.12 of 1995 concerning Corrections does not specifically regulate community participation. This becomes one of the inhibiting factors for the community to play an active role in carrying out supervision of correctional institutions.

\section{Suggestions}

In order to optimize the participation of the community, it is important for legislators to think about creating participatory correctional regulations in an integrated manner by harmonizing and synchronizing various existing laws and regulations. At least two things 
can be done: 1) The first alternative, revision. against Law no. UU no. 12 of 1995 concerning Corrections, by including a Special Chapter on the Role of Community Participation in Supervision of Correctional Institutions in Corruption Prevention Efforts in Correctional Institutions. 2) The second alternative, Creating a special regulation in the form of a law that specifically regulates the Role of Community Participation in Supervision of Correctional Institutions in efforts to prevent corruption.

\section{BIBLOGRAPHY}

\section{Books}

Arifin. Buku Pendidikan Anti Korupsi Untuk Perguruan Tinggi. Jakarta: Kementerian Pendidikan dan Kebudayaan RI, 2011.

Baringbing, RE Catur Wangsa Yang bebas Kolusi Simpul mewujudkan supremasi Hukum. Jakarta: Pusat Kajian Reformasi, 2001.

Evi, Hartanti. Tindak Pidana Korupsi. Jakarta:Sinar Grafika, 2008.

Indriyanto, Adji. Korupsi Kebijakan Aparatur Negara dan Hukum Pidana Jakarta:Diadit Media, 2006.

Juwono, Vishnu. Melawan Korupsi: Sejarah Pemberantasan Korupsi Di Indonesia 1945-2014. Edited by Candra Gautama and Ining Isaiyas. Jakarta: Kepustakaan Populer Gramedia, 2018.

Rahardjo, Satjipto. Membedah Hukum Progresif. Jakarta: Penerbit Kompas:Jakarta, 2006.

Rianto, Bibit Samad. Bunga Rampai Potret Penegakan Hukum di Indonesia. Jakarta: Komisi Yudisial Republik Indonesia, 2009.

Sulhin Iqrak, Diskontinuitas Penologi Punitif,Sebuah Analisis Genealogis Terhadap Pemenjaraan (Jakarta:Prenada Media
Group,2016)

\section{Journal}

Hariadi, Agus. "Suatu Dilema Dalam Pembinaan Narapidana Koruptor Di Lembaga Pemasyarakatan." Jurnal Legislasi Indonesia 13, no. 3 (2016): 303. https://e-jurnal.peraturan.go.id/index.php/jli/article/ view/157.

Khairi, Mawardi. "Partisipasi Masyarakat Dalam Upaya Penegakan Hukum Peraturan Daerahpersepektif Teori Negara Hukum." Selisik 3, no. 1 (2017): 94. http:// journal.univpancasila.ac.id/index.php/ selisik/article/view/658.

Kurniawan, Teguh. "Peranan Akuntabilitas Publik Dan Partisipasi Masyarakat Dalam Pemberantasan Korupsi Di Pemerintahan." Bisnis \& Birokrasi, Jurnal Ilmu Administrasi dan Organisasi 16, no. 2 (2009): 119. http://journal.ui.ac.id/index.php/jbb/ article/view/612.

Pohan, Sarmadan. "Perbandingan Lembaga Anti Korupsi Di Indonesia Dan Beberapa Negara Dunia." JUSTITIA : Jurnal Ilmu Hukum dan Humaniora 1, no. 1 (2018): 271-303. http://jurnal.um-tapsel.ac.id/index.php/Justitia/article/view/44.

Thalib, Hambali, Ahmad Ramadhan, and Hardianto Djanggih. "The Corruption Investigation In The Regional Police of Riau Islands, Indonesia." Rechtsidee Universitas Muhammadiyah Sidoarjo 4, no. 1 (2017): 71-86. http://ojs.umsida.ac.id/index.php/rechtsidee/article/view/988.

Waluyo, Bambang. "Optimalisasi Pemberantasan Korupsi Di Indonesia." Jurnal Yuridis 1, no. 2 (2014): 169-182. https://ejournal.upnvj.ac.id/index.php/Yuridis/article/ view/149.

Widyastuti, Anastasia Reni. "Disfungsionalisasi Birokrasi Sebagai Kendala Dalam 
Pemberantasan Korupsi." Yustisia Jurnal Hukum 4, no. 3 (2015): 684. https://jurnal. uns.ac.id/yustisia/article/view/8700.

\section{Internet}

Aziz, Abdul. "Mengapa Napi Korupsi Terus Ditempatkan Di Lapas Sukamiskin?" Tirto.Id. Last modified 2018. Accessed February 8, 2020. https://tirto.id/mengapanapi-korupsi-terus-ditempatkan-di-lapassukamiskin-cPEt.

Baskoro, Rangga. "90 Persen Peredaran Narkoba Berasal Dari Dalam Lapas, Pengendalian Cukup Dengan Ponsel." Wartakotalive.Com. Last modified 2019. Accessed February 8, 2020. https:/wartakota.tribunnews.com/2019/12/02/90-persen-peredaran-narkoba-berasal-dari-dalam-lapas-pengendalian-cukup-dengan-ponsel.

Hakim, Rakhmat Nur. "Pimpinan DPR Minta Napi Koruptor Tak Diistimewakan Di Lapas." Kompas.Com. Last modified 2018. Accessed December 5, 2020. https://nasional.kompas.com/ $\mathrm{read} / 2018 / 07 / 24 / 14081701 /$ pimpinan-dprminta-napi-koruptor-tak-diistimewakandi-lapas.

"Indeks Persepsi Korupsi Indonesia Pada 2020 Melorot 3 Poin." Antaranews.Com. Last modified 2021. Accessed February 9, 2021. https://www.antaranews. com/berita/1972407/indeks-persepsikorupsi-indonesia-pada-2020-melorot3-poin\#: :text=Jakarta (ANTARA) - Indeks Persepsi,dari 180 negara yang disurvei.

Ihsanuddin. "Kronologi OTT Kalapas Sukamiskin Dan Terungkapnya Fasilitas 'Wah' Para Napi." Kompas.Com. Last modified 2018. Accessed January 18, 2021. https://nasional.kompas.com/ $\mathrm{read} / 2018 / 07 / 22 / 05332271 /$ kronologi-ott- kalapas-sukamiskin-dan-terungkapnyafasilitas-wah-para-napi?page=all.

"TPK Berdasarkan Instansi." KPK Komisi Pemberantasan Korupsi. Last modified 2021. Accessed February 2, 2021. https:// www.kpk.go.id/id/statistik/penindakan/ tpk-berdasarkan-instansi.

"TPK Berdasarkan Profesi/Jabatan." KPK Komisi Pemberantasan Korupsi. Last modified 2021. Accessed February 2, 2021. https://www.kpk.go.id/id/statistik/penindakan/tpk-berdasarkan-profesi-jabatan.

\section{Law and Regulation}

Criminal Code Procedure

Government Regulation of the Republic of Indonesia on Number 43 of 2018 Concerning Procedure for Implementing Community Participation and Awarding in the Prevention and Eradication of Corruption

Law of the Republic of Indonesia on Number 12 of 1995 Concerning Correctional Institution

Law Number 30 of 2020 Concerning Corruption Eradication Commission

Law of the Republic of Indonesia on Number 28 of 1999 Concerning the State Organizer Who Is Clean and Free from Corruption, Collusion, and Nepotism

Law of the Republic of Indonesia on Number 31 of 1999 Juncto Law Of the Republic of Indonesia on Number 20 of 2001 Concerning Corruption Eradication 